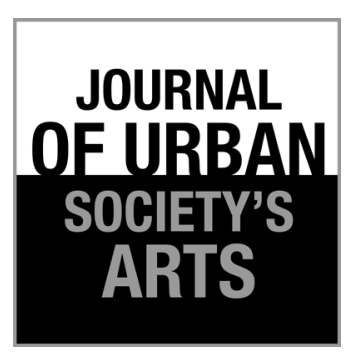

Volume 7 Nomor 2,

October 2020: 109-117

\section{Bansi Organology: Minangkabau Wind Instrument Production of Hamdan Thawil in Padangpanjang}

\section{Hengki Armez Hidayat}

Prodi Pendidikan Sendratasik, Fakultas Bahasa dan Seni, Universitas Negeri Padang Jl. Prof. DR. Hamka, Air Tawar, Padang.

Email: hengkiarmez@fbs.unp.ac.id; HP.: +6282283100911

\section{Yensharti}

Prodi Pendidikan Sendratasik, Fakultas Bahasa dan Seni, Universitas Negeri Padang Jl. Prof. DR. Hamka, Air Tawar, Padang.

Email: yensharti68@gmail.com

Saaduddin (Author Corresponden)

Fakultas Seni Pertunjukan, Institut Seni Indonesia Padangpanjang

Jl. Bahder Johan, Kota Padangpanjang.

Email: hanyadidin@gmail.com; HP.: +6281371972228

\begin{abstract}
This research examines the production process of making Minangkabau wind instrument, Bansi, produced by Hamdan Thawil. This research began by observing the stages of making Bansi, then about production factors that affect the production process. The results of this study include; 1) the selection and processing of raw materials, 2) the use of tools, 3) the manufacturing phase of Bansi and the factors of production; 1) natural resource factor, 2) human resource factor, 3) capital resource factor and 4) expertise/ skill factor. The research was conducted with a case study approach and using qualitative methods. Data collection techniques were carried out using participatory observation, interviews, documentation, and triangulation.
\end{abstract}

Keywords: Bansi Organology; Hamdan Thawil; Minangkabau wind instrument

\begin{abstract}
ABSTRAK
Organologi Bansi: Alat Musik Tiup Minangkabau Produksi Hamdan Thawil di Padangpanjang. Penelitian ini mengkaji proses produksi pembuatan alat musik tiup Minangkabau, Bansi, produksi Hamdan Thawil. Penelitian ini dimulai dengan mengamati tahapan pembuatan bansi, kemudian tentang faktor-faktor produksi yang mempengaruhi proses produksi. Hasil penelitian ini meliputi; 1) pemilihan dan pengolahan bahan baku, 2) penggunaan alat, 3) tahap pembuatan bansi dan faktor produksi; 1) faktor sumber daya alam, 2) faktor sumber daya manusia, 3) faktor sumber daya permodalan dan 4) faktor keahlian/keterampilan. Penelitian dilakukan dengan pendekatan studi kasus dan menggunakan metode kualitatif. Teknik pengumpulan data dilakukan dengan observasi partisipatif, wawancara, dokumentasi, dan triangulasi. Kata kunci: Organologi Bansi; Hamdan Thawil; alat musik tiup Minangkabau
\end{abstract}

\section{Introduction}

Bansi is a traditional instrument of Minangkabau that has been played by its people in the past time untill today. Formerly, Bansi as personal entertainment was played by farmers and teenagers during their spare time in the rice fields or on the beach while resting under resting huts or tending livestock. The presence of Bansi is a must in a cultural event. It becomes a media that is able to give and add the sacredness of the event, especially in these days when the community has 
a mindset to preserve and inherent cultural arts in their lives and existence as national character and characteristic swhich represents its people in general and Minangkabau people specifically. Like wise with the existence of local content courses in formal educational institutions such as in the Department of Arts. Thus, learn how to play Bansi has an educational function in maintaining and preserving the values of local wisdom. Tilaar argues that education and culture are two elements that cannot be separated because they are binding. Culture lives and develops because of the educational process, whereas education only exists in a cultural context (Tilaar, 2011)

Bansi as an educational and performance media is required to have its own standard. The standards include sound quality, materials quality, aesthetic form, neatness, and its durability. Therefore, sound as the art of music is determined by the quality of the instrument body that producing the sound itself. It means that producing Bansi with good quality in sound cannot be separated from the structure of the instrument itself. The choice of materials and how they are made will certainly affect the quality of the sound produced. Thus, crafts that do not consider the details of the process of making Bansi causing poor sound quality. It reflects the lack of knowledge regarding the standardization of the creating process and in the selection of raw materials. therefore, Bansi needs to be studied organologically. As stated by Bintarto AG, In a music learning process, every music medium has features that are important to study (Bintarto, 2014).

The concept of local wisdom-based education according to Asmani (2012: 30) is education that utilizes local excellence in economic, cultural, linguistic, information and communication technology, ecology, and others that are all beneficial for the development of student competencies. Students of the Department of Language and Arts at Universitas Negeri Padang are prospective educators or teachers who are expected to master arts and culture. To have competent students, a lecturer must first develop his knowledge by carrying out the responsibilities of the Three Pillars of Higher Education (Education, Research and
Community Engagement). Then, the context of education in art and culture is inseparable from the activity of digging up information about art and culture itself, especially regarding the study of an instrument that can be used as an object of research.

There are many inflatable instruments been created by craftsmen in Minangkabau, West Sumatera. The researcher has also observed the quality of the instrument from some craftsmen that the researcher know. The researcher chose one of the main craftsmen who took part in making Bansi for educational media and the performing arts, especially on making Minangkabau inflatable instruments. The person was Hamdan Thawil.

Hamdan Thawil often receives requests and orders from formal and non-formal education environments, such as secondary schools, universities, vocational and music education as well as traditional Minangkabau art studios in West Sumatera. Some of them are coming from out of the area of West Sumatera and abroad too. This wide sales market caused by the good quality of the Bansi production that makes the consumers are satisfied and often reorder the product. However, Bansi made by Hamdan Thawil is a traditional handmade and has not been produced in a large scale or mass produced as in the production of musical instrument factories because he does everything alone without any help from others. The difficulties of finding raw materials for the type of bamboo needed, the simple tools used, the needs of technology for better and faster production, and its marketing method are still dependent on ordering.

For this reason, this research is important to be conducted since it can contribute to local wisdombased art education. Then, it motivates craftsmen to develop and advance their business in the production of Minangkabau inflatable instruments. Thus, it will economically help craftsmen's living. This research is a case studies research on Bansi as an object and Hamdan Thawil as the subject.

\section{Method}

This research was conducted by applying a case study approach in qualitative research methods. 
Creswell in Sugiyono (2014: 14) explains a case study approach is the type of approach used to investigate and understand an existed event or problem by gathering various kinds of information that are processed to get a solution. This case study is in line with research conducted by Arga Budaya, which in its case study research on bansi found data stating that the use of bansi in the community in Saruaso is a manifestation of culture, which contains ritual, metaphoric and folkloric values (Budaya, 2012).

Population and sampling method in this study used the concept of natural settingby observing the production of Bansi by Hamdan Thawil. Hamdan Thawil was the research subject as well as individual in this study, while Bansi as the object that observed based on organology studies. Data collection techniques were carried out using an observation sheet, interview, documentation, and triangulation.

The case study approach makes researchers an instrument that is supported by documentation tools and field notes. The qualitative data that the authors obtained from interviews and direct observations were then analyzed descriptively by emphasizing musical analysis. This research was relevant to be classified as an organology study, especially for art academics who want to learn the Minangkabau wind instrument. At the same time, it was used to understand the effort of craftsmen in producing goods or services that were observed through the factors of production.

\section{The Process of Making Bansi}

Pono Banoe (2003: 312) defined that organo$\operatorname{logy}$ is the science of musical instruments, the study of the structure of musical instruments based on sound sources, how to produce sounds and tuning systems. This study discussed the process of making Minangkabau instrument organology by Hamdan Thawil. The crafting of Minangkabau wind instruments, especially Bansi, was carried out through several stages in the production process. These stages were; 1) raw materials selection and processing, 2) tools using, 3) the stage of making Bansi.

\section{Raw Materials Selection and Processing}

The main raw material in making Bansi was bamboo. The bamboo chosen was Talang bamboo that has good quality for making Bansi. This type of bamboo grows in a highland or mountainous area. It belongs to a type of bamboo that is rarely found. So, it took effort to explore to find this type of bamboo with good quality.

Good quality of raw material in making Bansi depends on the bamboo age. It must be in the right age; too old bamboo will make Bansi attacked by termites or beetles. The characteristics of a good bamboo were; it had dried and peeling petal, no "miang" attached
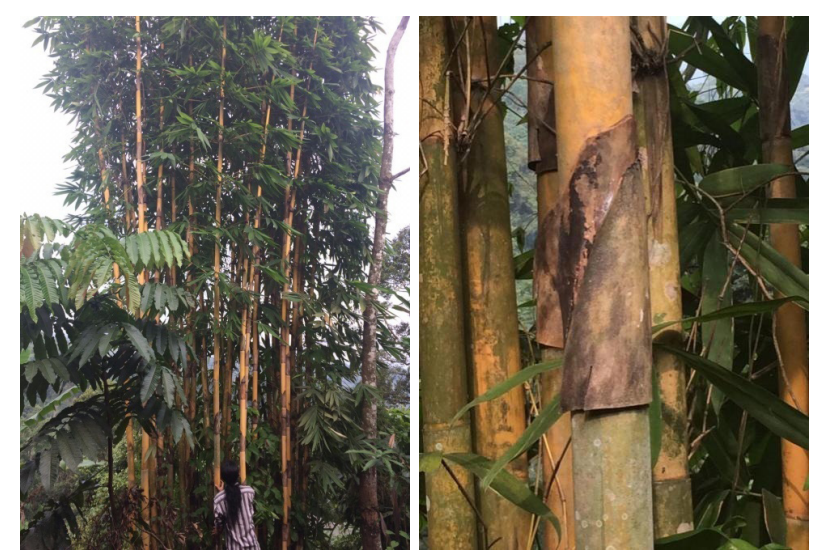

Figure 1. Talang Bamboo type and Talang shape with fairly old age as raw material. Documentation: Hengki, 2019.

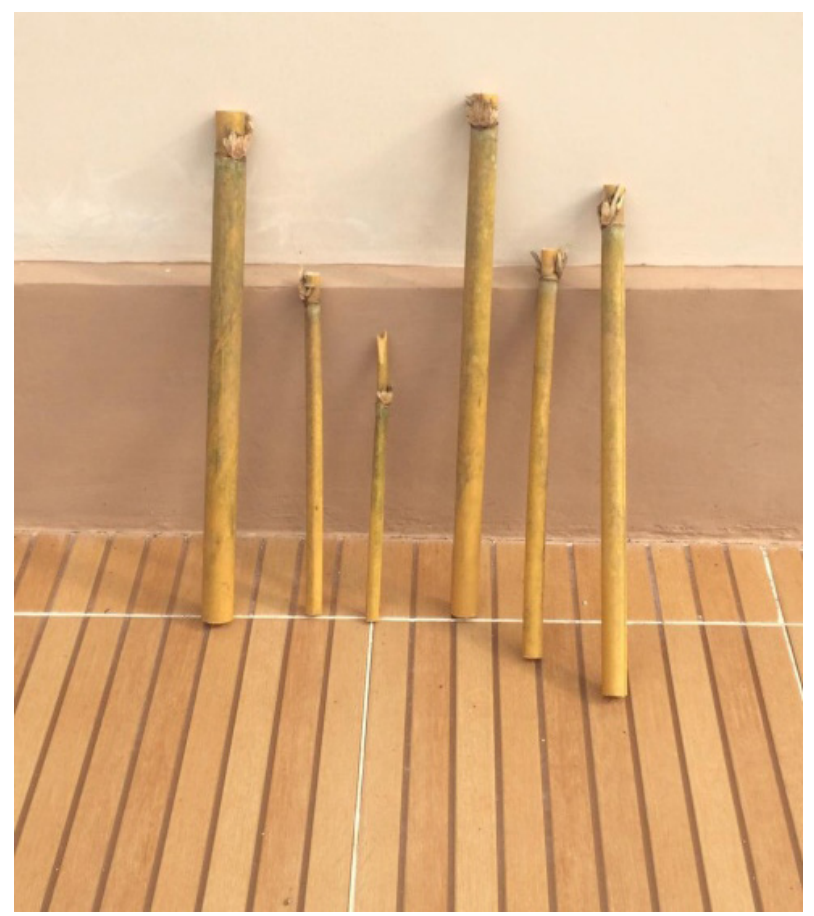

Figure 2. The process of drying Talang raw material with direct sunlight. Documentation: Hengki, 2019. 
to the stem section of the Talang, it had brown leaves have started to brown or not too brown or dry.

The process of Talangas an instrument to be used in making Bansi was rigged after the selection or before the measurement process. The researcher cown and cleaned its branches and leaves, cut it down into several pieces, then cut into one segment. The next is the process of drying Talang. Then, it should be dried in a clean andright placein direct sunlight. Drying raw Talangcan take a week or more and is very dependent during the drying process. Drying of raw materials by utilizing direct sunlight aims to eliminate the water content in Talang. So that the fiber has good quality for making Bansi.

\section{Use of Tools}

The use of tools was determining the production process of making Bansi. Bansiwas a type of handmade instrument that used a fairly simple tool.

The tools used in Bansi production;

a. Machete, used as Talang logging tool.

b. Saws, used as cutting tools for raw material.

c. A knife, used as a tool to make holes in Bansi's pitch.

d. Coconut shell, used as an ornamentation or engraving tool on Bansi.
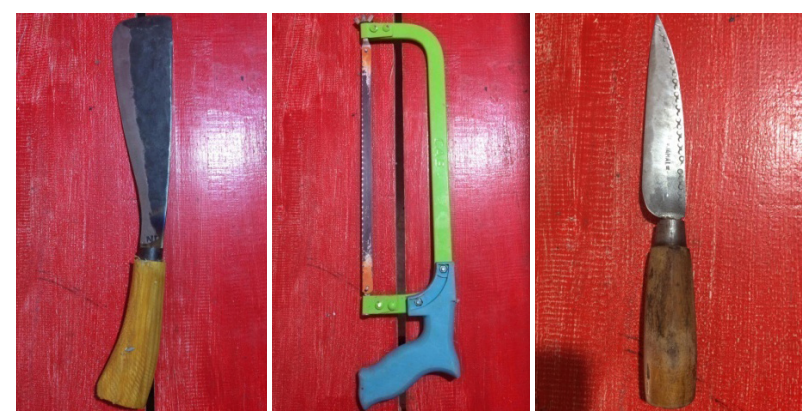

Figure 3. The tools used in the production process. Documentation: Hengki, 2019.

\section{Stage of Making Bansi}

The production phase was an important stage in the production process and studying the organology of Bansi. However, it must be ensured that the raw material condition was completely dry and Talang body was yellowish physically. It was first washed using sandpaper, especially on the surface or outer shell. Bansi production was described in systematical procedures; measurement, tuning, ornament carving, and finishing. These stages were described using the following tables and explanations;

\section{a. Measurement}

Talang size made to get Bansi with the tone $\mathrm{D}=$ do as the sample can be seen in the Table 1 .

In sum, cutting and holing Talang were done to get Bansi with the tone $\mathrm{D}=$ do. The sizing was $\pm 7.5 \mathrm{~cm}$ for inner circle diameter, upper ends hole diameter $\pm 0.7 \mathrm{~cm}$, the length from "suai" to the upper ends hole \pm 27.5 $\mathrm{cm}$, "suai" hole dimension length $\pm 1 \mathrm{~cm}$ and width of $\pm 0.7 \mathrm{~cm}$. The procedure at this stage was to make the first hole and "suai" in Talang. Then, cut to the blowhole at the base of the Talang with a distance of \pm 2.5
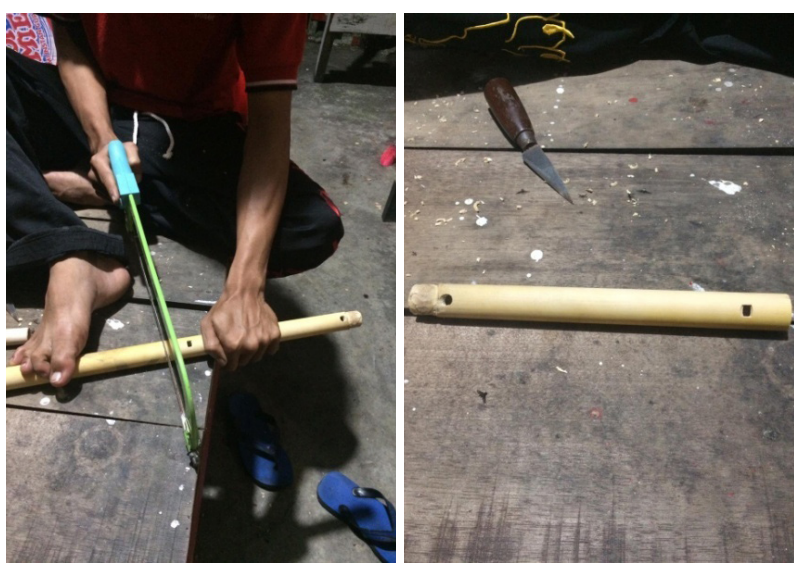

Figure 4. The Bansi base cutting and the distance of the first hole to "suai". Documentation: Hengki, 2019.

Table 1. Bansi $\mathrm{D}=$ do measuring stick.

\begin{tabular}{|c|c|c|c|c|c|}
\hline \multicolumn{6}{|c|}{ Bansi $\mathrm{D}=$ do size } \\
\hline \multirow{2}{*}{$\begin{array}{c}\text { Inner circle } \\
\text { diameter }\end{array}$} & \multicolumn{2}{|c|}{ "suai" hole dimension } & \multirow{2}{*}{$\begin{array}{l}\text { Upper ends } \\
\text { hole diameter }\end{array}$} & \multirow{2}{*}{$\begin{array}{l}\text { The length from } \\
\text { "suai" to the upper } \\
\text { ends hole } \\
\text { (B) }\end{array}$} & \multirow{2}{*}{$\begin{array}{c}\text { "suai" base } \\
\text { distance/ "suai" } \\
\text { blowing hole } \\
\text { (C) }\end{array}$} \\
\hline & $\begin{array}{c}\text { Length } \\
\text { (A) }\end{array}$ & Width & & & \\
\hline $\pm 7,5 \mathrm{~cm}$ & $\pm 1 \mathrm{~cm}$ & $\pm 0,7 \mathrm{~cm}$ & $\pm 0,7 \mathrm{~cm}$ & $\pm 27,5 \mathrm{~cm}$ & $\pm 2,5 \mathrm{~cm}$ \\
\hline
\end{tabular}


$\mathrm{cm}$ from the "suai". Thus, the overall length of Bansi with $\pm 7.5 \mathrm{~cm}$ in diameter was \pm 31 $\mathrm{cm}$ or total number $(\mathrm{A}+\mathrm{B}+\mathrm{C})$.

\section{b. Tuning}

The tuning process was the process of measuring the tone needed in the production steps of making a good quality Bansi. It was carried out using an android-based tuner application. A "suai" stopper was made before tuning the pitch. Stoppers were made from soft wood to make it easy to grind and attach to the base of Bansi. This section was very important in Bansis organological structure because this part determined the sounds produced. The size of the stopper was adjusted to the diameter of the Bansi base.

The tuning process was also determined

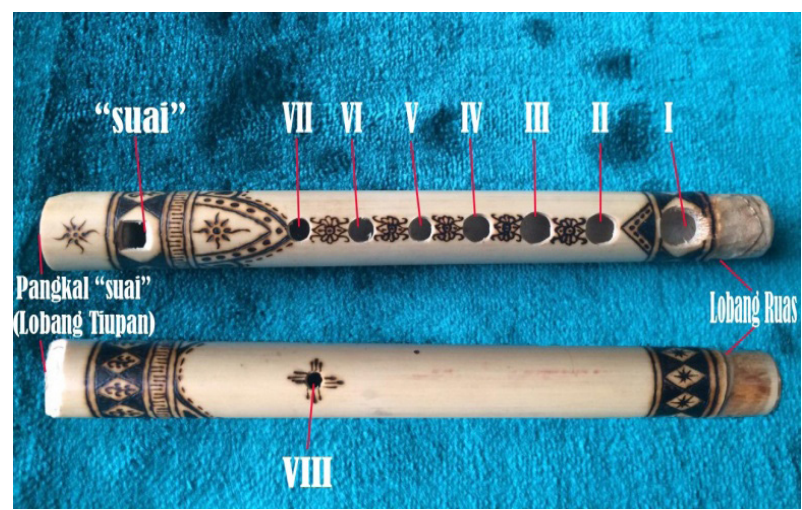

Figure 5. Blowing holes, "suai", hole tones (I-VIII) and internode. Documentation: Hengki, 2019. by the distances between the pitch of the tone hole. The distance of the tone hole was sorted from the bottom to upper end in different sizes as the process of tuning. This process was also referred as "ma-anak pisang". The distances between holes in Bansi was said to be as a bunch of bananas. The distance to the end was increasingly closer and the hole diameter was slightly smaller. Table 2 measured the size and distance of Bansi tones.

Bansi was a type of aerophone musical instrument in which the source of the sound was produced by blowing at the base of the body of this instrument. To produce the do, re, mi notes, the blowing technique and the position of the fingers were aligned to the pitch of the tone. It was done by opening the fingers in the notes hole 1, 2 and 3. To produce the notes fa, sol, la, si, do, blowing technique and the position of the fingers opened sequentially one by one in the note holes 4, 5, 6, 7, 8 in which the fingers closing the third hole. Meanwhile, to produce the tone of "pakiak" or high tone, blowing techniques and the position of the fingers close the holes 2, 3, and 4 tones.

\section{c. Ornament Carving}

Ornamentation was an element that strongly supports the aesthetics and form

Table 2. Holes and tones dimension.

Tuning tones of Bansi $\mathrm{D}=$ do

\begin{tabular}{cccc}
\hline Tone holes & $\begin{array}{c}\text { Tone holes } \\
\text { diameter }\end{array}$ & Tone holes space & Tone produced \\
\hline I & $\pm 8 \mathrm{~mm}$ & $\begin{array}{c}\text { Internode hole to I } \\
= \pm 0,5 \mathrm{~cm}\end{array}$ & D + 25 cen \\
II & $\pm 7 \mathrm{~mm}$ & I - II $= \pm 2 \mathrm{~cm}$ & E (Perfect) \\
III & $\pm 7 \mathrm{~mm}$ & II - III $= \pm 1,7 \mathrm{~cm}$ & Fis $+10 \mathrm{cen}$ \\
IV & $\pm 7 \mathrm{~mm}$ & III - IV $= \pm 1,5 \mathrm{~cm}$ & G $+10 \mathrm{cen}$ \\
V & $\pm 7 \mathrm{~mm}$ & IV - V $= \pm 1,4 \mathrm{~cm}$ & A (Perfect) \\
VI & $\pm 6 \mathrm{~mm}$ & V - VI $= \pm 1,3 \mathrm{~cm}$ & B (Perfect) \\
VII & $\pm 6 \mathrm{~mm}$ & VI - VII $= \pm 1,2 \mathrm{~cm}$ & Cis (Perfect) \\
VIII & $\pm 5 \mathrm{~mm}$ & VIII was between VI and & D (Octave) \\
& & VII, at the backside & \\
\hline
\end{tabular}


of Bansi. The carved oration used in Bansi gave at once a unity, balance, diversity, and complexity as the value of an art object. The integrity value of the carving motif described Minangkabau identity. The value of balance was illustrated by the arrangement of the motifs in such away. The diversity and complexity could be seen from the motifs used as ornamentation.

The ornaments used were distinctive carvings in the form of motifs that characterize Minangkabau culture. Minangkabau traditional ornament is a form of physical culture born from the art system owned by the community (Syafwandi, 2018). The identical carving motifs used were "taratai", "pucuak rabuang" and "rangkiang". The "taratai" implied survival, "pucuak rabuang" meant firmness and "rangkiang" as a storage place implied life reserve.

The process of engraving Bansi ornamentation was carried out using a burned coconut shell. The shell was burned at the edges and tapered to coals and turn red. The emboldened and reddish shell was then

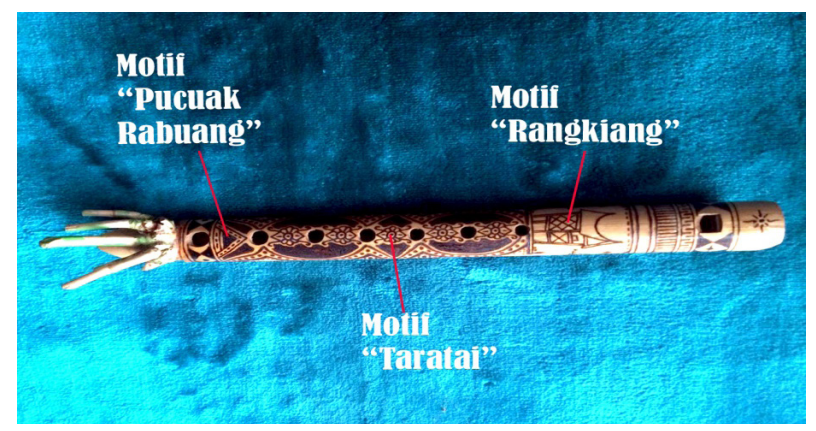

Figure 6. The carving motif on Bansi as ornamentation. Documentation: Hengki, 2019.

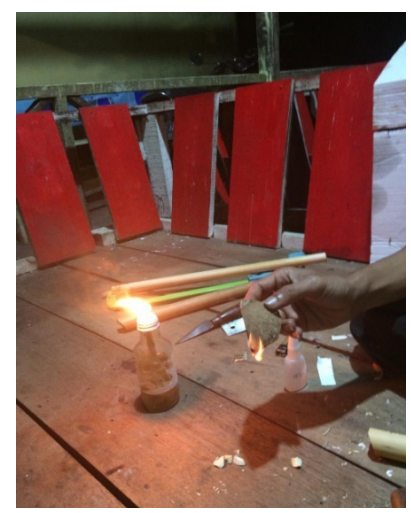

Figure 7. The burned shells for carving. Documentation: Hengki, 2019. affixed to the surface of the Talang following the motif lines that had been made with a pencil before.

This ornamentation workmanship stage required patience and perseverance. The carving was done first by working on the main lines of the motif and filling the motifs. Embers at the end of the shell must be blown continuously so that the intensity of the fire was maintained the engraving stage ended.

\section{d. Finishing}

Finishing was the last stage in the process of making Bansi. It was done by re-checking the notes needed on Bansi, as well as tidying the parts on Bansi. The unmatched tones were fixed by reforming the holes and checking the base of the "suai" or blowing hole. This procedure was conducted to check the quality of Bansi sound.

The final procedure was painting the outer surface of the Bansi. The paint used was transparent spray paint. It was done by heating the surface of Bansi and drying it under the sun directly or heating it on stoves. When Bansi's surface is hot enough $\left( \pm 50^{\circ}\right.$

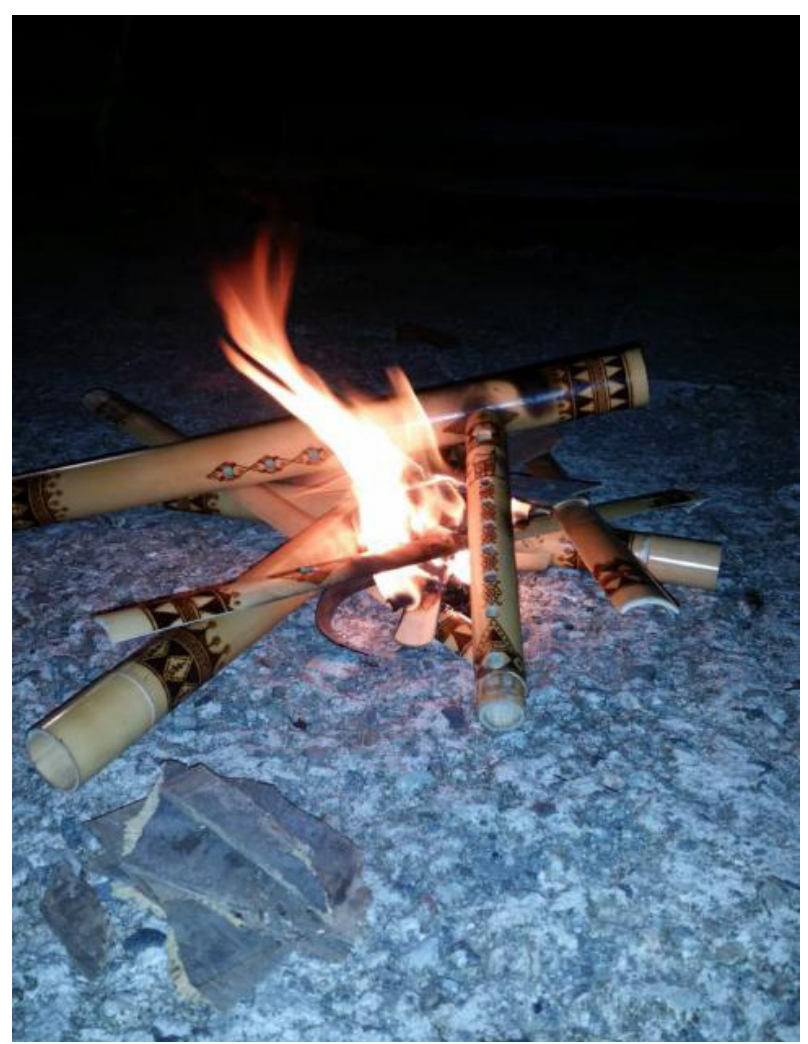

Figure 8. Wind instruments that were burned because of the powder. Documentation: Hengki, 2019. 
C), then the paint was sprayed on the surface smoothly and perfectly.

\section{Production Factors}

\section{Natural Resources Factor}

Natural resources defined as something provided by nature that can be utilized by a human. The raw material for making Bansi was available in nature. The material was the type of bamboo that was known as Talang in Minangkabau. Talang was commonly found in the highlands or mountains area in Minangkabau.

The difficulty of finding Talang made the production run slowly since it was very rare to find people who cultivate Talang. More over, the craftsmen like Hamdan Thawil had to go exploring to remote corners of the village to be able to find it. If they found some, they would call the owner first before going to the site and asked whether it could be cut down or not.

Talang usually bought from farmers at a price of Rp. 10,000, - each. It was cut with the size of one or two segments then put into a sack and carried on a motorcycle. One sack could spend Rp. 300,000 to Rp. 500,000. There were around 30-50 Talang or more in one sack. Finally, they were selected based on the needs of the instrument size.

However, Talang as the main raw material for making Bansi was also vulnerable to disease. It was in the form of powder that appeared on the Talang fibers. This damage was caused by the presence of caterpillar such as termites or beetles that lived and thrived when Talang was placed in an unclean and moist place. It was the most serious case in the production of wind instruments. Additionally, the wind instrument damage could be a great loss for craftsmen.
Therefore, this powder disease could infected others. One Talang got the disease, it would spread to the others. This case was experienced by Hamdan Thawilduring his effort making Bansi. The total lost he had out of 50 pieces of Bansi with price at Rp. 100,000, - was 5 million. The lost was also about the time and effort due to the instrument damage caused by powder problem.

\section{Human Resources Factor}

This sense could be meant as the ability of a human to improve their use and develop their product. In this study, human resource was Hamdan Thawil. He was a craftsman of the Minangkabau wind instrument with educational background Bachelor of Arts (S.Sn) from Department of Art Karawitan, the Indonesian Institute of Art, Padang Panjang. He also worked as a traditional Minangkabau artist and a mentor at Silat Harimau Singgalangin Bukit Tinggi. He had developed his skills in making the Minangkabau wind instrument since 2003. He learned it from the natural philosophical value, making him a multi-talent in terms of skills and expertise in the place where he served (Silat Harimau Singgalang).

In the production process, he was sometimes assisted by some workers. How ever, they just did carvings or ornaments. He did alone for other procedures such as cutting and measuring. It made his Bansi special since it had its own characteristics in tone.

In summary, Bansi was a wind instrument classified as a handmade art product. The craft in making or producing this instrument was done simply by hands without using a machine at all. For this reason, the skill of a craftsman was needed goods and simple tools support.

Table 3. Tone measurement comparison.

\begin{tabular}{|c|c|c|c|c|c|c|c|}
\hline \multicolumn{8}{|c|}{ Convensional tone measurement $\mathrm{D}=\mathrm{do}$} \\
\hline $\mathrm{D}$ & $\mathrm{E}$ & Fis & G & A & B & Cis & $\mathrm{D}$ (octave) \\
\hline \multicolumn{8}{|c|}{ Hamdan Thawil's tone measurement $\mathrm{D}=\mathrm{do}$} \\
\hline $\mathrm{D}$ & $\mathrm{E}$ & Fis & $G$ & $\mathrm{~A}$ & $\mathrm{~B}$ & Cis & D (octave) \\
\hline+25 cen & & +10 cen & +10 cen & & & & \\
\hline
\end{tabular}


However, the technology used was the androidbased application to measure the tones.

\section{Financial Resources Factor}

This factor could be meant as cost needed in making Bansi. Further, the capital was not only about money, but it can also be in the form of relations, production sites, investment in goods, and tools that were owned and used in the production process.

a. The main capitals owned and keep by Hamdan Thawil were relations and trust. He introduced his product directly to the consumers. Besides, he was well-known with his relation to others too. Consumers who were planning to buy Bansi and trying to find information about it would get a recommendation from other consumers who had ever ordered from him. They could contact him directly or entrust other consumers too. Thus, the trust could be established among relations and consumers.

b. The production site which was currently owned by Hamdan Thawil was located at Mega Mendung, Malibou Anai, Padang Pariaman Regency. It was located between Jalan Lintas Padang Panjang - Padang. The access to this site was easily accessible by consumers from Padang Panjang, Bukitinggi, Padang Pariaman, or Padang.

c. The goods and tools used by Hamdan Thawil were quite simple and traditional. The place he used as the selling site was defined as investment in place. Therefore, the goods and tools used in the production process were Talang, work tables, saws, machetes, blades, and carving tools (coconut shells) for ornamentation or carving.

\section{Skill Factor}

The skill factor was defined as individual skills in managing products that were produced and it was related to the quality of the products. The expertise possessed by Hamdan Thawil in making Bansi had its own characteristics that made it special and different from others. his is in accordance with the meaning of the work of art as an expression of the inner experience of the artist who is above all visions through reasoning (Arya Sucitra, 2015). This states that Hamdan Thawil's expertise in making Minangkabau wind instruments has characteristics that come from the product he produces. The specialties of his product were in the way of measuring the tone and the distinctive features of his ornament or carving.

Furthermore, his tone measurement used unique tuning techniques skill. It was different from the usual tone sizes used in conventional scales. The tone characters were found in notes I, III, and IV (D +25 cen, Fis +10 and $G+10)$. These three notes were intentionally made because they were Bansi's characters. He had his own reasons as his specialties.

The last, carving motifs as ornaments on Bansi were aesthetic aspects that support the quality of Bansi. This aspect was also a distinctive skill from Hamdan Thawil. There were only some craftsmen who were skilled and able to think to makea very simple way ornamentation. It required patience and perseverance to produce attractive and aesthetic Bansi in its qualitythat characterized Minangkabau as well as the identity set forth by the craftsmen of Bansi. This expertise was outlined in the form of "rangkiang", "taratai" and "pucuakrabuang" motif. This reflects that the Minangkabau people hold the philosophy of "Alam Takambang Jadi Guru" (developing nature becomes teacher), meaning that all sources of knowledge and human behavior refer to nature, everything is learned by observing and looking at "Alam" (nature) (Hidayat et al., 2019). Likewise, as a Minangkabau person, Hamdan Thawil always studies "Alam" to produce Bansi which has its own philosophical meaning as the identity of his unique handiwork.

\section{Conclusions}

Organology as a study in studying musical instruments is an attempt to understand musical instruments as objects, whereas to understand musical instruments crafters is an effort to motivate 
themselves. In one side, the substance of crafting traditional musical instrument is fulfilling the necessities of life, on the other side, it is an effort to preserve culture. Bansi as an object becomes central to explore and know the other sides of its presence have benefits for society academically, economically and practically.

Bansi as objects made by craftsmen's hands is a work of art (handmade) since there is not everyone has special skills to make this thing, yet it can be learned. One of the reasons is the existence of this article as a reference or guideline in researching organological studies that are traced in the form of its production procedures, as for the research on Hamdan Thawil.

It should be noted that each culture has its own characteristics or uniqueness and so is Bansi as a cultural product of the Minangkabau people. It is possible that every craftsman of Bansi has his own characteristics in the technique of making his products. However, the simple work and a good quality product was a separate skill that requires precision, patience, and perseverance.

\section{References}

Asmani, J. M. (2012). Pendidikan Berbasis Keunggulan Lokal. Yogyakarta: DIVA Press.

Arya Sucitra, I. G. (2015). Transformasi Sinkretisma Indonesia dan Karya Seni Islam I Gede Arya Sucitra. Journal of Urban Society's Arts, 2(2), 89-103. https://doi.org/https://doi. org/10.24821/jousa.v2i2.1446

Bintarto, A. G. (2014). Aspek Olah Vokal Musik Klasik Barat pada Musik Populer. Journal of Urban Society's Arts, 1(1), 44-56. https://doi. org/10.24821/jousa.v1i1.787
Budaya, A. (2012). Alat Musik Tiup: Bansi dalam Ritual Penyadapan Enau di Nagari Saruaso Minangkabau. Ekspresi Seni, 14(1), 1-15. https://doi.org/http://dx.doi.org/10.26887/ ekse.v14i1.166

Hidayat, H. A., Wimbrayardi, W., \& Putra, A. D. (2019). Seni Tradisi Dan Kreativitas Dalam Kebudayaan Minangkabau. Musikolastika: Jurnal Pertunjukan Dan Pendidikan Musik, 1(2), 65-73. https://doi.org/10.24036/ musikolastika.v1i2.26

Hood, Mantle. (1964). The Ethnomusicologist. Ohio: The Kent State, University Press.

Moleong, J Lexy. (2006). Metodologi Penelitian Kualitatif. Bandung: PT. Remaja Rosdakarya.

Purba. (2014). Studi Organologi Siligun Simalungun Buatan Bapak Ja Huat Purba Desa di Desa Tengkoh Kecamatan Penombean Pane, Kabupaten Simalungan.

Rahardjo, Susilo \& Gudnanto. (2011). Pemahaman Individu Teknik Non Tes. Kudus: Nora Media Enterprise.

Sugiyono. (2014). Metode Penelitian Kuantitatif, Kualitatif, dan Kombinasi (Mixed Method). Bandung: Alfabeta.

Sugiyono. (2014). Metode PenelitianPendidikan Kuantitatif, Kualitatif, dan RひD. Bandung: Alfabeta.

Syafwandi, Z. (2018). Makna Filosofi Ornamen Hias Tradisional Minangkabau Masihkah Relefan Dengan Pola Kehidupan Masyarakat Sekarang. Ranah Seni, 12(1), 489-500. https://doi.org/https://doi.org/10.24036/ ranahseni.v12i01.36

Tilaar, H. A. (2011). Manajemen Pendidikan Nasional. PT Remaja Rosdakarya. 